\title{
Wuhan coronavirus spread in Russia: macroeconomic production function in regard to transport and communication infrastructure
}

\author{
Anton A. Afanasiev \\ E-mail: aanton@cemi.rssi.ru

\section{Olga S. Ponomareva} \\ E-mail: fondf@cemi.rssi.ru
}

Central Economics and Mathematics Institute, Russian Academy of Sciences

Address: 47, Nakhimovsky Prospect, Moscow 117418, Russia

\begin{abstract}
Transport and communication infrastructure plays an important role in ensuring economic growth, also in the context of the Wuhan coronavirus (SARS-CoV-2) spread worldwide. The role of the communication component increases with the epidemic and the associated restrictive measures, which replace, to a certain extent, the transport component. We offer an econometric study of the macroeconomic production function in the Russian Federation with transport and communication infrastructure (the fixed assets average annual value of the Russian transport and communications sectors) for 1990-2018. The arguments for this function are the average annual value of fixed assets in constant 1990 prices, the average annual rate of the use of production capacities in Russian industry, the average annual number of people employed in the national economy, the average annual value of fixed assets of transport and communications in constant 1990 prices. Our research demonstrates that in 2010-2018 the GDP elasticity to production infrastructure was decreasing. We explain this by the reduction in the volume of capital investments in the infrastructure sector's fixed assets. In addition, we offer an analytical modification of the macroeconomic production function for 2020 in the context of the spread of the Wuhan coronavirus among the Russian population by introducing into this function the average annual rates of labor and infrastructure capacity use, which, along with the average annual rate of fixed assets capacity use are functions of the predicted values of the daily number of the infected Russian citizens. These predicted values are calculated by the time dependent Gaussian quadratic exponent estimated by the least squares. We present the accuracy of the forecast
\end{abstract}


results for the 2020 spring trends of the daily number of Russian and Moscow population infected with the Wuhan coronavirus. The average APE forecast error for 30 days ahead for Russia is $10.4 \%$ and the same for five weeks for Moscow is $10 \%$. Moreover, we make forecasts of the officially published daily number of infected Russian population for fall 2020 - spring 2021.

Key words: econometric study; Russian economy; macroeconomic production function; transport and communication infrastructure; econometric forecasting; Wuhan coronavirus; SARS-CoV-2; COVID-19; rate of use of production factors.

Citation: Afanasiev A.A., Ponomareva O.S. (2020) Wuhan coronavirus spread in Russia: macroeconomic production function in regard to transport and communication infrastructure. Business Informatics, vol. 14, no 4, pp. 76-95. DOI: 10.17323/2587-814X.2020.4.76.95

\section{Introduction}

$\mathrm{T}$ The production infrastructure is of great importance to the national economy. In his Message to the Federal Assembly, the President of Russian Federation declares that its modernization and development play an important role in strengthening the country's framework, that they give impetus to the development of regions (including Crimea and Sevastopol) and contribute to economic growth [1]. In particular, the Crimean railway bridge, put into operation in 2019 , gave a powerful impetus to the development of the Republic of Crimea and the city of Sevastopol. Thus, the development of effective public policy measures for sustainable development, modernization and efficient use of production infrastructure, including its transport and communication component, using modern economic and mathematical tools is a priority.

A large amount of research has been devoted to the development and modernization of the Russian transport and communication infrastructure [2]. One of the pioneers in the study of Russian domestic infrastructure was Grigory D. Dubelir (1874-1942) whose works are devoted to the optimization of the road network [3-7].

In the expertise by N.P. Laverov et al. [8] conducted for the project of the construction of the international sea channel "Eurasia," it is stressed that a preliminary assessment finds possible rather high risks (including transport, economic, environmental, political and legal). The authors investigate the current state of near aquatic and aquatic ecosystems on the territory of the planned construction of the "Eurasia" channel and highlight the importance of additional engineering and environmental studies to clarify the territory's water resources, the necessity for a deeper study of the options for the consequences of the construction of this large water management facility. They also pay special attention to measures aimed at reducing the negative consequences of the project.

M.G. Zavelsky [9] introduces an econometric model for forecasting the main macroeconomic indicators for the regions of the Russian Federation taking into account the influence of the infrastructural factor and, in particular the gross regional product (GRP). This model takes into account the specifics of the Russian administrative-territorial units and allows us to predict with more accuracy the trends in changes in these indicators.

V.N. Livshits, I.A. Mironova and A.N. Shevtsov [10] substantiate the necessity of making State strategic decisions for the development of transport infrastructure based on assessing the socio-economic efficiency of investment projects. They also offer applications of their 
approach taking the example of investment projects for new railway construction in Russia.

E.I. Pozamantir [11] offers a computable general equilibrium model of the economy, where he examines the most important components of the transport infrastructure development strategy - the choice of sources and volumes of capital investment financing infrastructure development, including the impact of this choice on the development of the national economy and on final consumption. E.I. Pozamantir also simulates the formation of internal sources for financing an investment fund from the added value created in the previous period and presents the results of his experimental calculations.

Using methods of mathematical modeling and forecasting, V.A. Sadovnichy et al. [12] provide a quantitative assessment of the long-term effects (macroeconomic, social and geopolitical) of a project for the development of railways in the Far East and Siberia, including the construction of a high-speed passenger-and-freight highway. Their calculations show that the implementation of this project will play an important role in the socio-economic development of the Russian Federation as well as in strengthening the geopolitical and geo-economic positions of Russia in the Asia-Pacific region and globally.

At the same time, the problem of assessing the macroeconomic effect for the development and modernization of transport and communication infrastructure has not been fully resolved. It is primarily due to the concentration of researchers on one of its components: more often the transport component and less often the communication component. The latter, according to V.L. Makarov, plays an important role at the present stage of society's movement towards the knowledge economy [13]. The econometric model of the Russian economy's production function proposed by the authors [14] solves this problem by separating the average annual value of fixed assets of the pure transport and communications sectors ${ }^{1}$ into a separate function argument which makes it possible to assess the influence of infrastructure on such an important macroeconomic indicator of the Russian economy as gross domestic product (GDP) for the previous years 1990-2012. At this stage, it seems relevant to study the production function in the extended time interval 1990-2018 to further analyze the impact of infrastructure on Russian GDP.

\section{Production function model and statistics}

In order to assess the impact of the transport and communication infrastructure on Russia's GDP, we carried out an econometric study of the following macroeconomic production function, which was proposed earlier [14], for the time periods from 1990 up to 2013-2018:

$$
Y_{t}=\mathrm{e}^{\alpha}\left(z_{t} K_{t}\right)^{\beta} L_{t}^{1-\beta} I_{t}^{\gamma},
$$

where $Y_{t}$ is Russian GDP in constant 1990 prices for year $t$;

$K_{t}$ is average annual value of Russian economy fixed assets in constant 1990 prices for year $t$;

$z_{t}$ is the average annual rate of use of production capacities in Russian industry for year $t$;

$L_{t}$ is the average annual number of people employed in the national economy for year $t$;

$I_{t}$ is the average annual value of fixed assets of transport and communications in constant 1990 prices for year $t$.

The econometric study of function (1) was carried out by the least squares method based on statistical data from Rosstat and the Russian Economic Barometer (Table 1). The conver-

\footnotetext{
1 The fixed assets of the pure sectors of transport and communications are the fixed assets of transport and communications of all economic units regardless of their industry affiliation; i.e. the assets of the pure industries or sectors that are reflected in the balance of fixed assets compiled by Rosstat (Russian Federal State Statistics Service)
} 
Statistical data for the econometric study in 1990-2018

Table 1.

\begin{tabular}{|c|c|c|c|c|c|}
\hline Year & $Y_{t}$, billion rubles & $K_{t}$, million rubles & $z_{t}$ & $L_{t}$, thousands of people & $I_{t}$, million rubles \\
\hline 1990 & 644 & 1871649 & 100 & 75325 & 251548 \\
\hline 1991 & 612 & 1957288 & 100 & 73848 & 265806 \\
\hline 1992 & 523 & 2009054 & 73 & 72071 & 277320 \\
\hline 1993 & 478 & 2030396 & 74 & 70852 & 283913 \\
\hline 1994 & 417 & 2014984 & 61 & 68484 & 288435 \\
\hline 1995 & 400 & 1995229 & 60 & 66441 & 289518 \\
\hline 1996 & 386 & 1983823 & 54 & 65950 & 289351 \\
\hline 1997 & 391 & 1967098 & 54 & 64639 & 289427 \\
\hline 1998 & 371 & 1953216 & 55 & 63642 & 289773 \\
\hline 1999 & 394 & 1953747 & 62 & 63963 & 290439 \\
\hline 2000 & 434 & 1962932 & 66 & 64517 & 291581 \\
\hline 2001 & 456 & 1976006 & 69 & 64980 & 295215 \\
\hline 2002 & 477 & 1993845 & 70 & 65574 & 301557 \\
\hline 2003 & 512 & 2015564 & 73 & 65979 & 309364 \\
\hline 2004 & 549 & 2040209 & 74 & 66407 & 318011 \\
\hline 2005 & 584 & 2074736 & 76 & 66792 & 327755 \\
\hline 2006 & 632 & 2119496 & 78 & 67174 & 340138 \\
\hline 2007 & 686 & 2169707 & 80 & 68019 & 353854 \\
\hline 2008 & 722 & 2229842 & 77 & 68474 & 367701 \\
\hline 2009 & 665 & 2292706 & 65 & 67463 & 383787 \\
\hline 2010 & 695 & 2350079 & 72 & 67577 & 402597 \\
\hline 2011 & 725 & 2416816 & 78 & 67727 & 419318 \\
\hline 2012 & 750 & 2499424 & 79 & 67968 & 439598 \\
\hline 2013 & 760 & 2581327 & 78 & 67901 & 468506 \\
\hline 2014 & 765 & 2644159 & 77 & 67813 & 496133 \\
\hline 2015 & 744 & 2673133 & 75 & 68389 & 520271 \\
\hline 2016 & 742 & 2696319 & 77 & 68430 & 539786 \\
\hline 2017 & 753 & 2730170 & 79 & 68127 & 557465 \\
\hline 2018 & 771 & 2762511 & 78 & 68016 & 572441 \\
\hline
\end{tabular}

Sources: data for 1990-2012 [14] updated for 2008-2012, data for 1990-2017 [15] updated for 2017, data for 2018 [16-18], Rosstat (EMISS database), authors' calculations according to the methodology [14, 15]. 
sion of the average annual value of fixed assets of the pure transport and communications sectors into 1990 constant prices was carried out on the basis of statistical data from Rosstat by the author's methodology described in [14, 15]. It should be noted that, in contrast to the results of [14], the authors use a slightly changed average annual value of fixed assets of the pure transport and communications sectors in 1990 comparable prices for 2008-2012 which is associated with the revision of the fixed assets revaluation index in 2008-2009. In addition, due to the revision of the average annual price index for investment products in Russia for 2017, equal to 1.026 , in contrast to [15], the authors use the updated average annual value of fixed assets of the national economy in 1990 constant prices for 2017. Due to the 2016 change of the methodology for calculating the average annual number of people employed in the national economy by Rosstat in order to proceed to an accurate comparison with the data for previous years, we calculate the values for 2017-2018 by average annual growth rates for 2017 and 2018 [15, 16].

\section{Results of the econometric study}

As a result of an econometric study of function (1) for the extended time intervals 19902018, it turns out (Table 2) that this function appropriately describes the process of expanded reproduction of the Russian economy both from the point of view of economic theory and the classical econometric criteria.

Relying on the table the following may be highlighted.

1. Signs at the coefficients of the production function are consistent with the provisions of economic theory.

\section{Results of an econometric study of the Russian economy's production function in regard to infrastructure (1) for 1990-2018}

\begin{tabular}{c|c|c|c|c|c}
\multirow{2}{*}{ Time period } & \multicolumn{2}{|c|}{ Coefficients and (in brackets) } & $t$-statistics & \multirow{2}{*}{$R^{2}$} & \multirow{2}{*}{$D W$} \\
\cline { 2 - 4 } & $\alpha$ & $\beta$ & $\gamma$ & 0.91 & 2.10 \\
\hline $1990-2003$ & $-7.84(-2.27)$ & $0.83(10)$ & $0.03(0.10)$ & 0.91 & 1.99 \\
\hline $1990-2004$ & $-11.15(-4)$ & $0.87(11)$ & $0.28(1.25)$ & 0.92 & 1.93 \\
\hline $1990-2005$ & $-12.94(-6)$ & $0.89(11)$ & $0.42(2.27)$ & 0.93 & 1.88 \\
\hline $1990-2006$ & $-14.18(-7)$ & $0.90(12)$ & $0.52(3)$ & 0.94 & 1.83 \\
\hline $1990-2007$ & $-15.09(-9)$ & $0.91(12)$ & $0.59(4)$ & 0.95 & 1.71 \\
\hline $1990-2008$ & $-16.13(-11)$ & $0.91(12)$ & $0.67(6)$ & 0.95 & 1.53 \\
\hline $1990-2009$ & $-17.01(-14)$ & $0.89(12)$ & $0.74(7)$ & 0.96 & 1.69 \\
\hline $1990-2010$ & $-16.36(-16)$ & $0.89(12)$ & $0.69(8)$ & 0.95 & 1.33 \\
\hline $1990-2011$ & $-15.29(-14)$ & $0.89(10)$ & $0.61(7)$ & 0.94 & 1.01 \\
\hline $1990-2012$ & $-14.28(-13)$ & $0.86(9)$ & $0.53(5)$ & 0.94 & 0.82 \\
\hline $1990-2013$ & $-13.40(-13)$ & $0.85(8)$ & $0.47(5)$ & 0.93 & 0.70 \\
\hline $1990-2014$ & $-12.67(-12)$ & $0.85(8)$ & $0.41(4)$ & 0.93 & 0.64 \\
\hline $1990-2015$ & $-11.97(-12)$ & $0.87(8)$ & $0.35(4)$ & 0.92 & 0.57 \\
\hline $1990-2016$ & $-11.31(-12)$ & $0.88(8)$ & $0.30(3)$ & 0.91 & 0.50 \\
\hline $1990-2017$ & $-10.80(-11)$ & $0.88(7)$ & $0.25(3)$ & 0.91 & 0.47 \\
\hline $1990-2018$ & $-10.46(-11)$ & $0.88(7)$ & $0.23(2.3)$ & & \\
\hline
\end{tabular}


2. All arguments of the function, i.e. factors of production, are statistically significant.

3 . High values of the coefficients of determination $R^{2}(0.91-0.94)$ indicate the presence of a very close goodness-of-fit between Russia's GDP and production factors (fixed assets, the number of employees, and fixed assets of infrastructure).

4. The fact that the Durbin-Watson $D W$ statistic falls into the zone of positive autocorrelation reduces, to some extent, the model's verification, but at the same time indicates the influence on Russia's GDP of other unaccounted factors, such as the world oil price, which was investigated by the authors in [15].

Moreover, the production function (1) has a fairly good predictive power for 2005-2018. Thus, the direction of the trend lines of the $e x$ post forecast of Russia's GDP coincides almost everywhere with the direction of the trend lines of the actual GDP (Figure 1), and the errors of the ex-post forecast, calculated by the formula: $A P E_{t}=\left|Y_{t(\text { forecast })} / Y_{t(\text { (actual })}-1\right|$ do not exceed $11 \%$ except for two years (Figure 2).

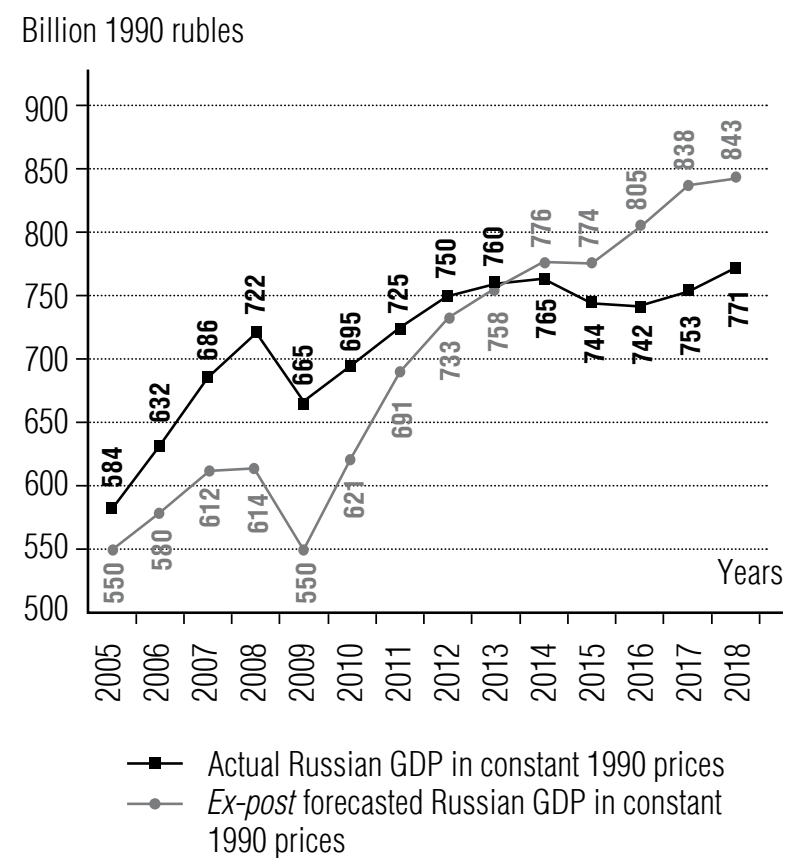

Fig. 1. Actual and ex-post forecasts for 2005-2018 Russian GDP in 1990 constant prices made by function (1) estimated in 1990-2004

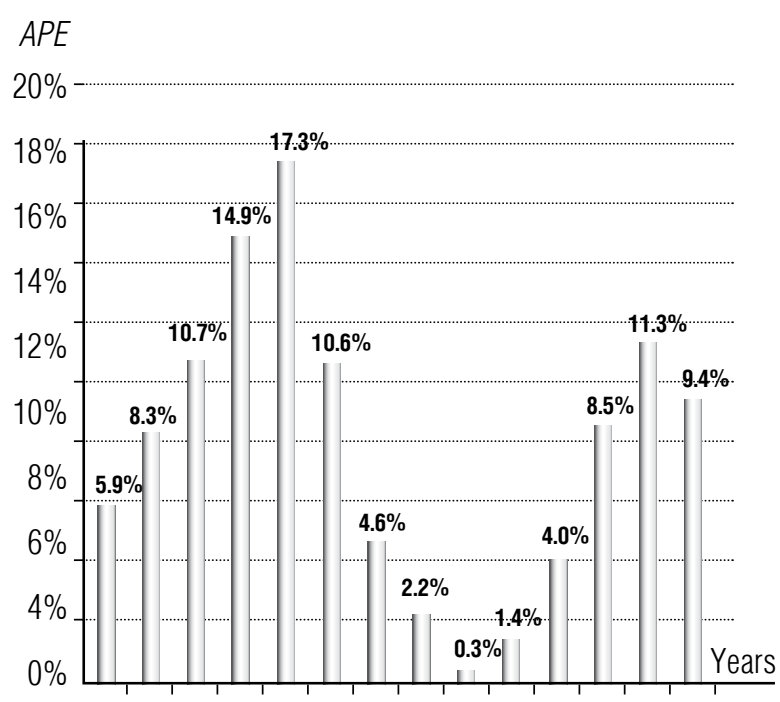

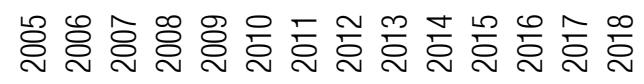

Fig. 2. Ex-post forecast errors APE of Russia's GDP in 1990 comparable prices for 2005-2018 made by function (1) estimated in 1990-2004

\section{Conclusions from the results of the econometric study}

Based on the results of econometric research (Table 2), we come to the following conclusions.

1. Russian GDP elasticity to production infrastructure $\gamma$, which characterizes the contribution of infrastructure to GDP reproduction, increased in 2003-2009 from 0.03 to 0.74 and decreased in 2009-2018 from 0.74 to 0.23 (Figure 3).

2. A decrease of 3.5 times (from 8 to 2.3 ) in the value of $t$-statistics of the coefficient for the infrastructure $\gamma$ during 2010-2018 indicates a weakening of the statistical significance of infrastructure and, consequently, its impact on the expanded reproduction of Russia's GDP.

One of the important factors indicating a decrease in the role of transport and communication infrastructure in the Russian economy since 2009 is a decrease in the weight (tonnage) of goods transported by all modes of transport in Russia in 2009-2018 (Figure 4). Thus, in 20032008 tonnage increased from 8.8 to 9.5 billion tons, while in 2009 it fell to 7.5 billion tons, and even though in subsequent years 2010-2018 the 
weight of the transported goods began to grow, it could not even reach the 2003 level.

What are the reasons for the decline in the role and importance of infrastructure in the expanded reproduction of the Russian national economy in 2009-2018?

In our opinion, the main reason for this decline is the reduction in capital investments in the Russian transport and communication infrastructure.

Indeed, in 2003-2009 the average annual rise of physical volume of investments in fixed assets of the pure transport and communications sectors was $117.2 \%$, and in 2010-2018 it was only $99.4 \%$ (calculated by the authors based on the data in Figure 5).

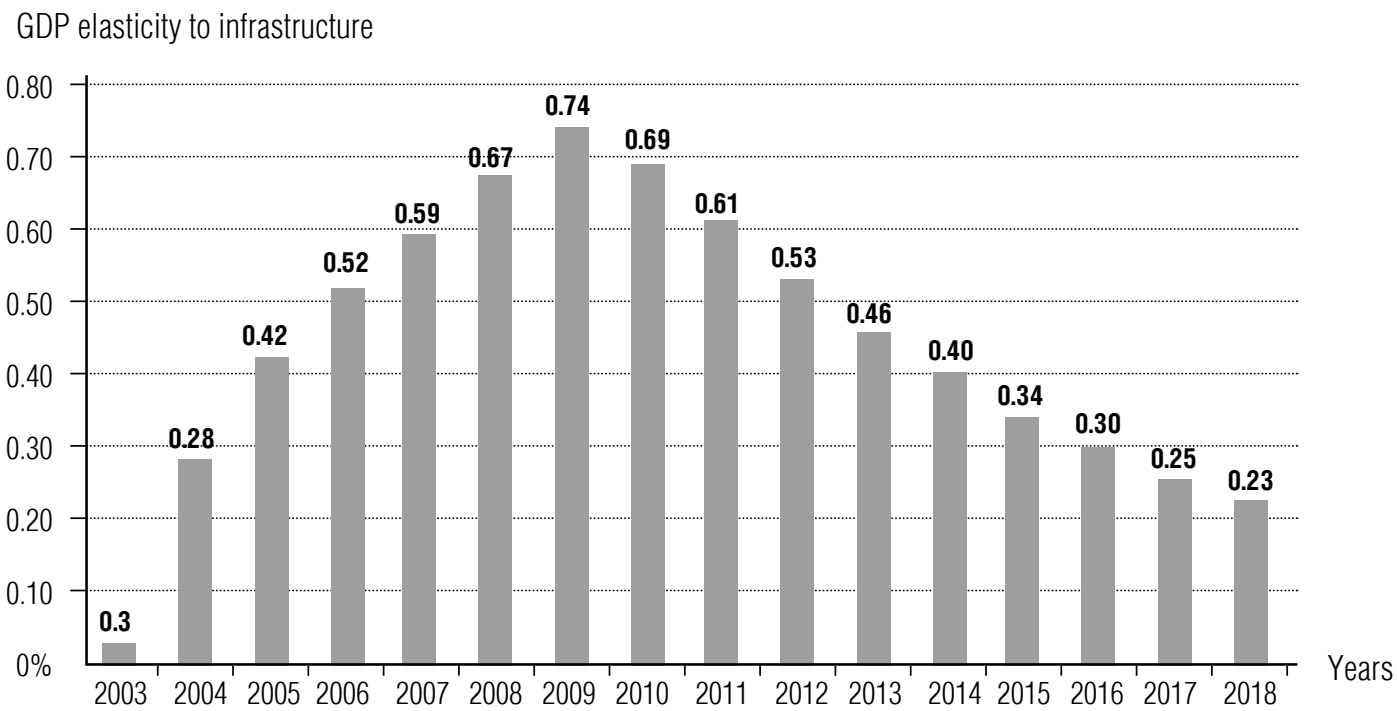

Fig 3. Russian GDP elasticity to production infrastructure $\gamma$ for 2003-2018 (Table 1)

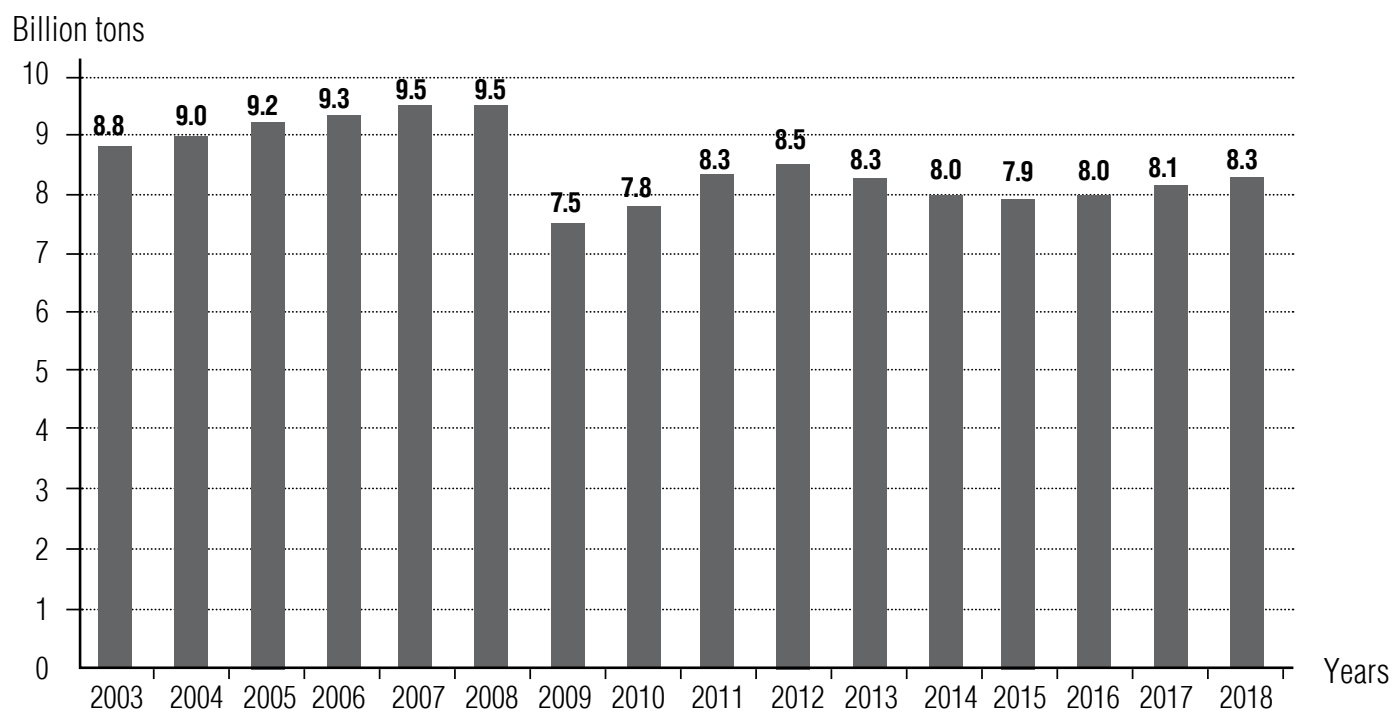

Fig. 4. Transportation of goods by all modes of transport in the Russian Federation in 2003-2018 Source: Rosstat (EMISS database) 


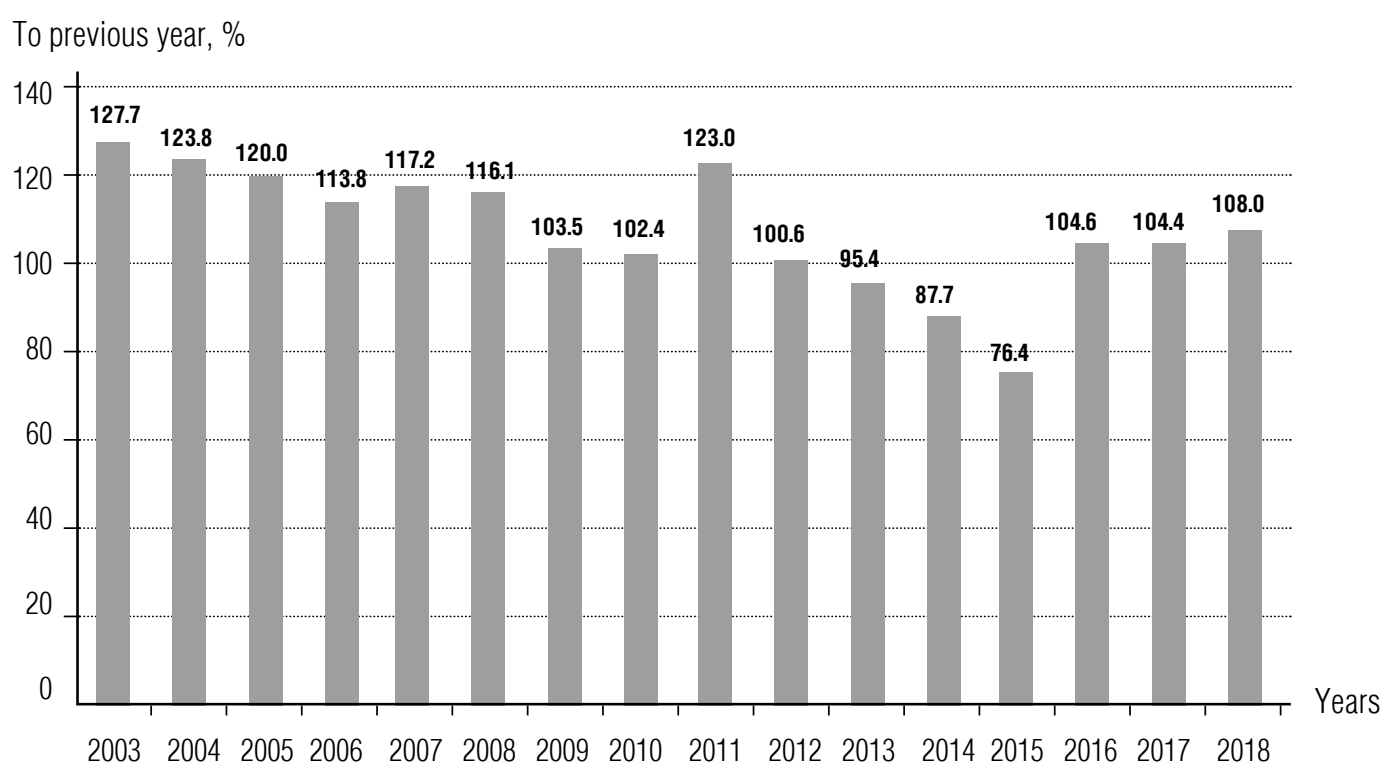

Fig. 5. Index of physical volume of investments in fixed assets for the full range of organizations for Russia's pure transport and communications sectors in 2003-2018. Source: Rosstat (EMISS database) and authors' calculations for 2017-2018

Thus, we see that today the transport and communication infrastructure of the Russian economy needs significant capital investments aimed at its effective modernization and sustainable development. It will, in turn, contribute to the acceleration of growth and sustainable development of the entire Russian national economy.

Meanwhile, since the beginning of 2020, the movement towards sustainable development and the acceleration of economic growth in both the Russian and world economies have been undermined by the wide spread of coronavirus disease 2019 (COVID-19), caused by the Wuhan coronavirus transmitted from person to person. The Wuhan coronavirus [22, 23] is the severe acute respiratory syndrome coronavirus 2 (SARS-CoV-2), which first appeared on the seafood market in the Chinese city of Wuhan in December 2019. Below we will use the term Wuhan coronavirus, which, along with the terms SARS-CoV-2, COVID-19, 2019$n C o V$, Wuhan seafood market pneumonia virus, is commonly used in scientific literature [22]. It is the original name of this novel coronavirus (proposed by Chinese researchers [22], including the Chinese Academy of Sciences [23]) and it is understandable to a wider range of readers with no medical background.

In the absence of specific anti-coronavirus medications, an anti-coronavirus vaccine and (at the initial stage) a sufficient amount of personal protective equipment, the Wuhan coronavirus, which started (according to official data) to actively spread in Russia from the end of February 2020, led to losses among the population. It forced the Russian State authorities to introduce, starting from March 2020, restrictions of varying severity on the movement of people, communication and the economic activities of enterprises and organizations. These restrictions, on the one hand, helped to slow the spread of the Wuhan coronavirus but, on the other hand, caused some damage to the Russian economy. In this respect, it seems relevant to modify the macroeconomic production function of Russia, in regard to the Wuhan coronavirus spread and the subsequent epidemic restrictions. 


\section{Modification of the model in regard to the Wuhan coronavirus spread for 2020}

One of the co-authors of this article offered and investigated by the least squares method an econometric model for the spring phase of the daily spread of Wuhan coronavirus cases in Russia (dated 10 May 2020 [20, 21]) and Moscow (dated 26 April 2020 [19]):

$$
y_{T}=\mathrm{e}^{a T^{2}+b T+c},
$$

where $y_{T}$ is the number of people infected with the Wuhan coronavirus per day;

$T$ is time (day);

e is the base of natural logarithm.

The results of the study are shown in Table 3. The functions investigated in [19-21] predict the daily number of people infected from 2 May 2020 to the end of July 2020 (Russia, Figures 6 and 7) and from 26 April 2020 to early July 2020 (Moscow, Figures 8 and 9).
As we can see in Figure 6, function 2 (Table 3) indicated the forecast date of the peak number of Russian citizens infected with the Wuhan coronavirus (13 May 2020, 11,618 people) two days after the actual peak (11 May 2020, 11,656 people).

Function 1 (Table 3, Figure 8) predicted a peak in the number of infected Muscovites on 6 May 2020 (5821 people), i.e. the day before the peak of the actual incidence on 7 May (6703 people), with an error in the number of infected citizens of Moscow equal to $13 \%$ (Figure 9). Functions (2) studied in [19-21] predicted the daily number of Russian citizens infected with the Wuhan coronavirus 30 days ahead, on 2-31 May 2020, with an arithmetic mean $A P E$ error of $10.4 \%$ (Figures 6 and 7, Table 3) and Moscow citizens for five weeks ahead, on 26 April - 1 May (function 15, Table 3) and 2-29 May 2020 (function 1, Table 3), with an arithmetic mean APE error of $10 \%$ (Figures 8 and 9), where

\section{Results of an econometric study for the quadratic exponential}

(Gaussian) function (2) of the daily number of people infected

with the Wuhan coronavirus in Moscow and across Russia, spring 2020

Table 3.

\begin{tabular}{|c|c|c|c|c|c|c|c|c|c|c|}
\hline \multirow[b]{2}{*}{ № } & \multirow{2}{*}{$\begin{array}{c}\text { Time } \\
\text { period }\end{array}$} & \multicolumn{3}{|c|}{$\begin{array}{l}\text { Coefficients } \\
t \text {-statistics }\end{array}$} & \multirow[b]{2}{*}{$R^{2}$} & \multirow[b]{2}{*}{$D W$} & \multicolumn{2}{|c|}{$\begin{array}{l}\text { Daily infection } \\
\text { peak forecast } \\
\text { for } 2020\end{array}$} & \multicolumn{2}{|c|}{$\begin{array}{l}\text { Onset of zero (single) daily } \\
\text { infection forecast for } 2020\end{array}$} \\
\hline & & $a$ & $b$ & $c$ & & & date & $\begin{array}{l}\text { number } \\
\text { of } \\
\text { infected, } \\
\text { persons }\end{array}$ & date & $\begin{array}{l}\text { total number } \\
\text { of people infected since the } \\
\text { beginning of the epidemic, } \\
\text { thousand people }\end{array}$ \\
\hline \multicolumn{11}{|c|}{ Moscow } \\
\hline 1 & $12.03-11.04$ & $\begin{array}{r}-0.0025 \\
(-1.43) \\
\end{array}$ & $\begin{array}{l}0.2788 \\
(5)\end{array}$ & $\begin{array}{l}0.8896 \\
(2.23)\end{array}$ & 0.88 & 2.70 & 6.05 & 5821 & 7.07 & 206.5 \\
\hline 15 & $12.03-25.04$ & $\begin{array}{c}-0.0030 \\
(-5)\end{array}$ & $\begin{array}{c}0.2935 \\
(11)\end{array}$ & $\begin{array}{c}0.8158 \\
(3)\end{array}$ & 0.93 & 2.68 & 29.04 & 3080 & 23.06 & 100.6 \\
\hline \multicolumn{11}{|c|}{ Russia } \\
\hline 2 & $2.03-1.05$ & $\begin{array}{c}-0.0018 \\
(-14)\end{array}$ & $\begin{array}{c}0.2648 \\
(31)\end{array}$ & $\begin{array}{l}0.3659 \\
(2.79)\end{array}$ & 0.99 & 1.07 & 13.05 & 11618 & 28.07 & 484.9 \\
\hline
\end{tabular}

Sources: [19-21] (numbering of functions is kept as in the original sources) 


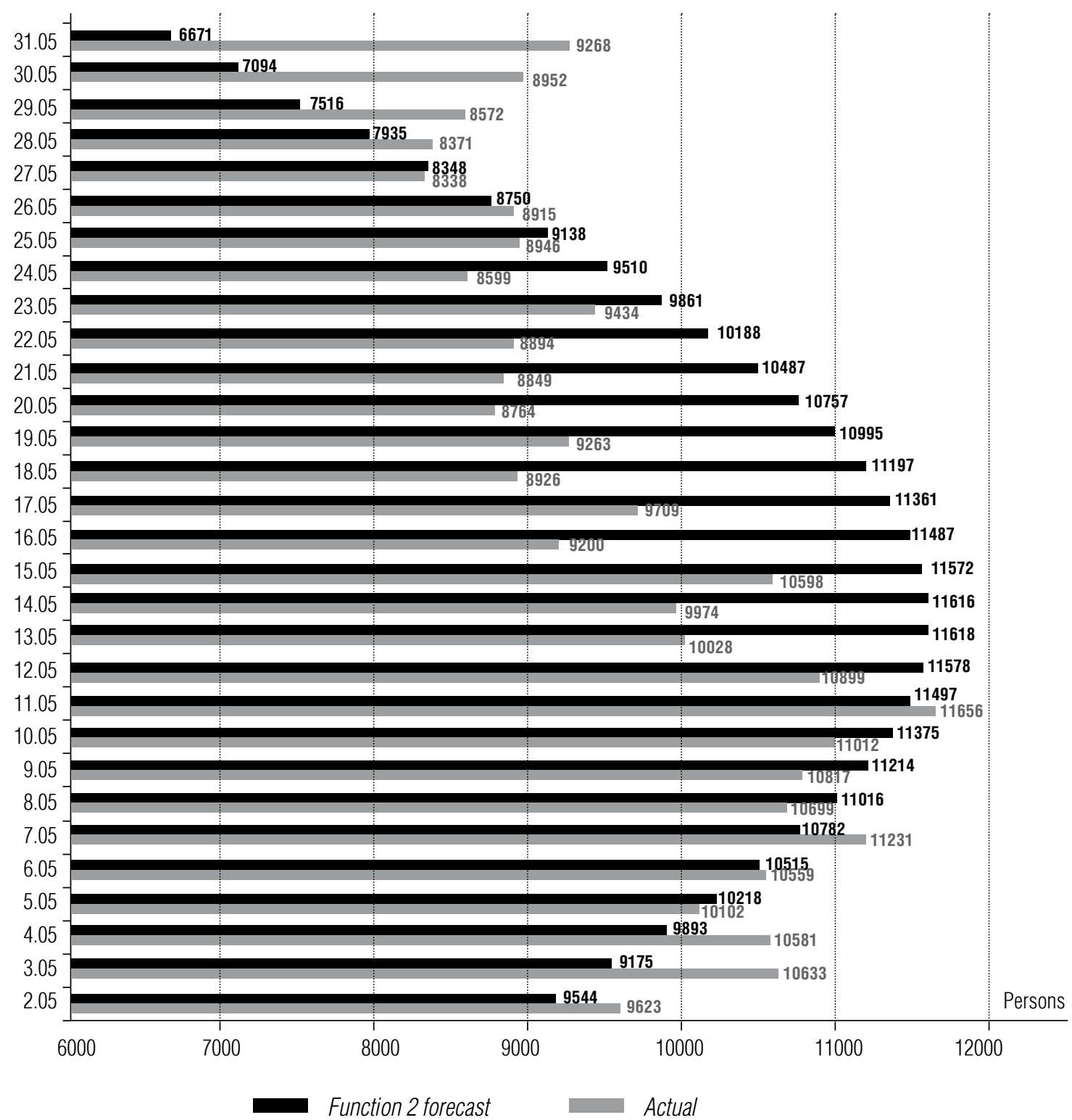

Fig. 6. Actual and forecasted values of the daily number of people infected with the Wuhan coronavirus in Russia for 2-31 May 2020 according to function (2) (Table 3) Source: [19] and "стопкоронавирус.рф"

$$
\begin{gathered}
A P E=\sum_{T=1}^{m} A P E_{T}, \\
A P E_{T}=\left|y_{T(\text { forecast })} / y_{T(\text { actual })}-1\right|
\end{gathered}
$$

$m$ is number of days of the forecast period.

A feature of the methodology of econometric forecasting by function (2) is that the degree of accuracy and scientific validity of the forecast, as well as confidence in it, depends not only on the correctly selected type of func- tional dependence, but also on how many of the estimated functions are confirmed by the forecast. Thus, the degree of confidence in the forecast is higher if the same or close values are predicted by a function estimated not over one time interval, but over several intervals. Indeed, all functions (2) for Russia (except one), estimated in the time intervals from 2 March 2 to 30 April - 10 May 2020, predict the same dates for the peak daily number of Russian citizens 


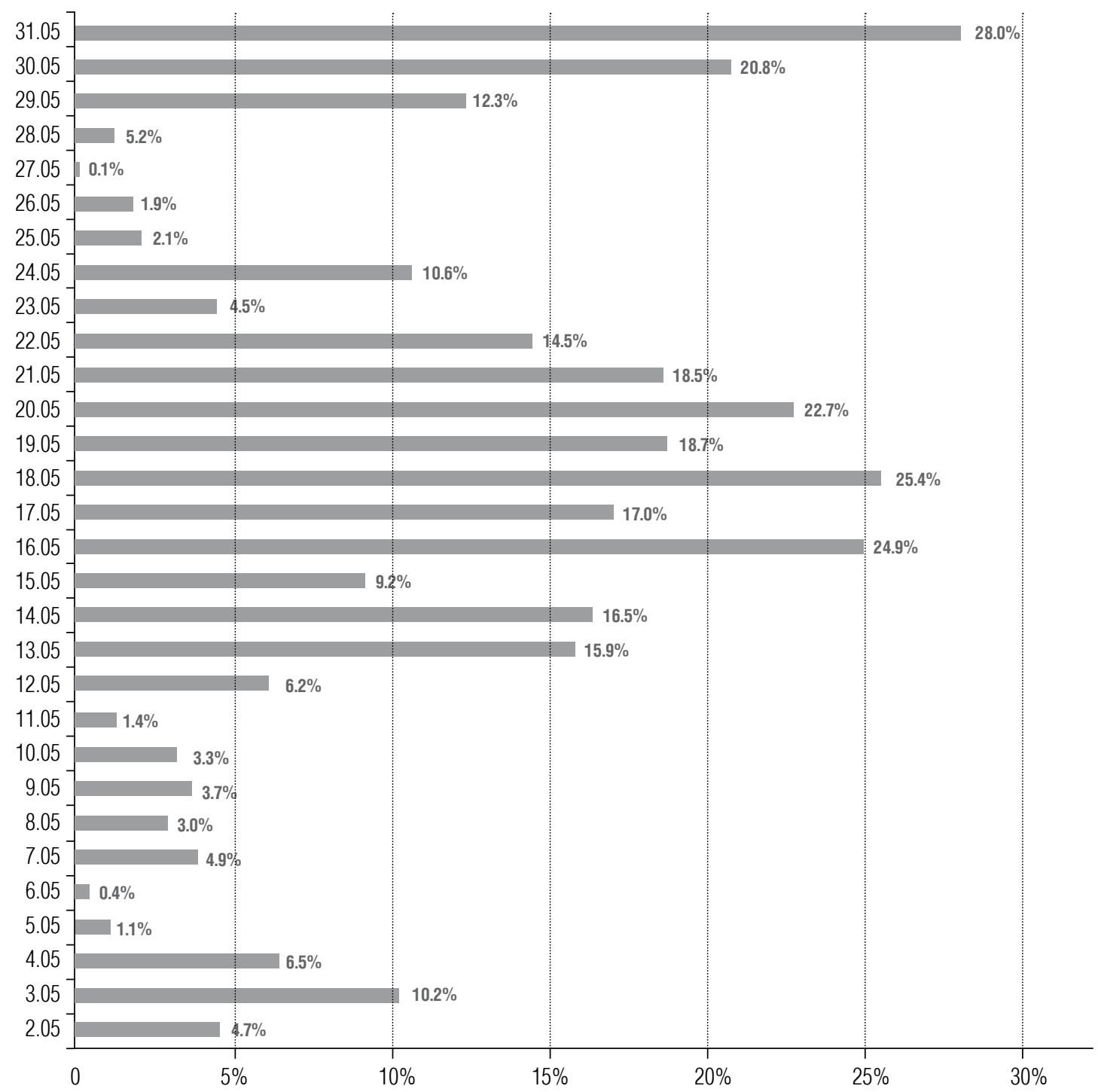

Fig. 7. APE forecast errors of the daily number of people infected with the Wuhan coronavirus in Russia for 2-31 May 2020 according to function (2) (Table 3 and Figure 6)

infected with the Wuhan coronavirus - 14 May 2020. Only one of the functions (2), studied from 2 March to 1 May 2020, predicts reaching the peak the day before - 13 May 2020, which is very close to the actual peak date -11 May 2020 (Figure 10). In addition, all 11 functions predict very close (within 5\% error) values of the peak daily cases in the range of 11.6-12.2 thousand people, which are very close to the actual peak daily cases on 11 May - 11.7 thousand people (Figure 11).
In addition, all these functions indicated very close dates of attenuation (onset of zero values) of the Wuhan coronavirus spread: 28 July (5 functions) and 29 July 2020 (the remaining 6 functions) (Figure 12). Despite the fact that the coronavirus in Russia was not defeated on these dates, there was a significant attenuation of its spread to 5.3-5.4 thousand people per day. It should be noted that significant discrepancies between the predicted and actual values of the daily number of Russia and Moscow citizens 


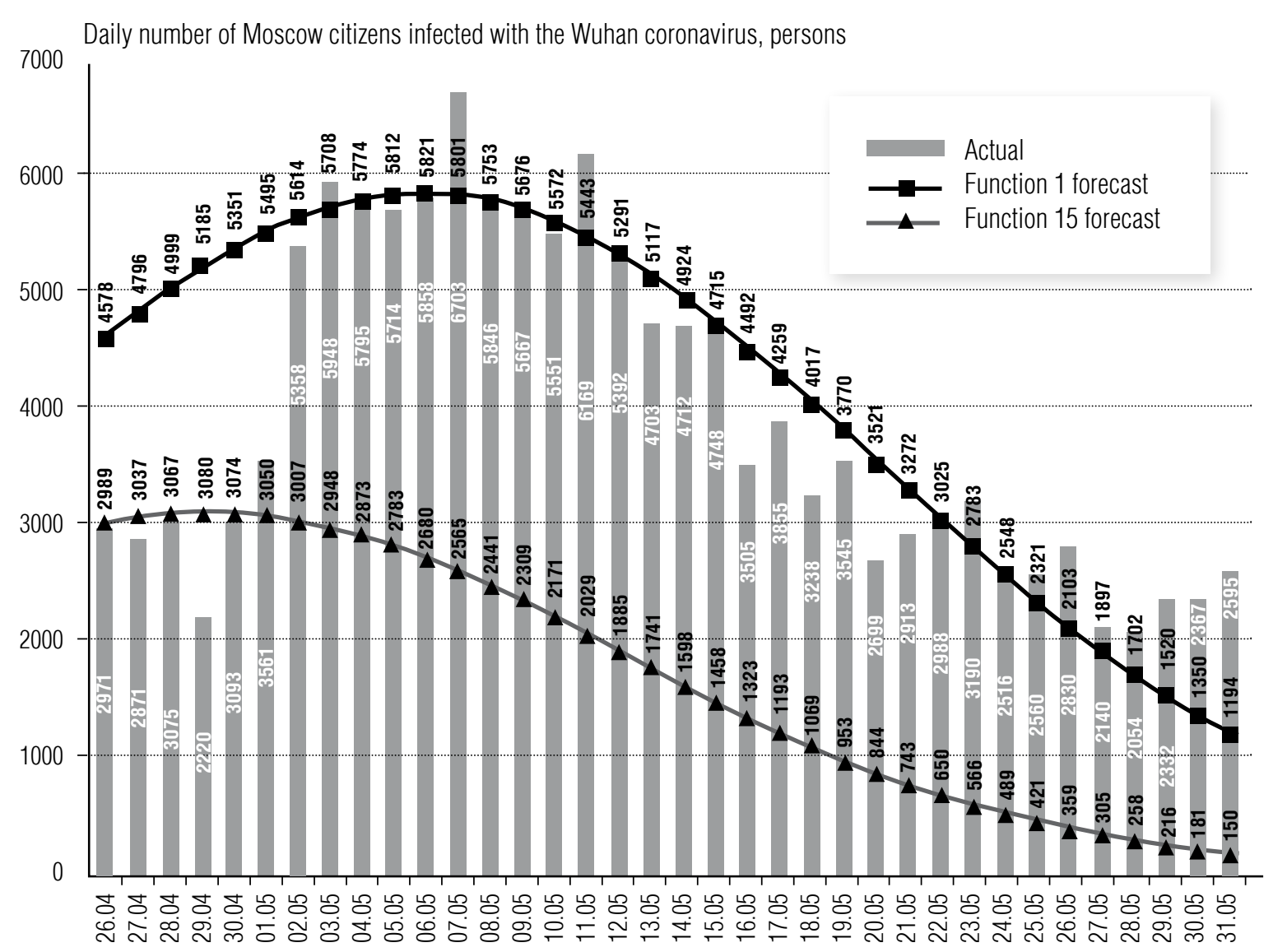

Fig. 8. Actual and forecasted values of the daily number of Moscow citizens infected with the Wuhan coronavirus for 26 April - 31 May 2020 according to functions 1 and 15 (Table 3). Source: [19-21] and "стопкоронавирус.рф"

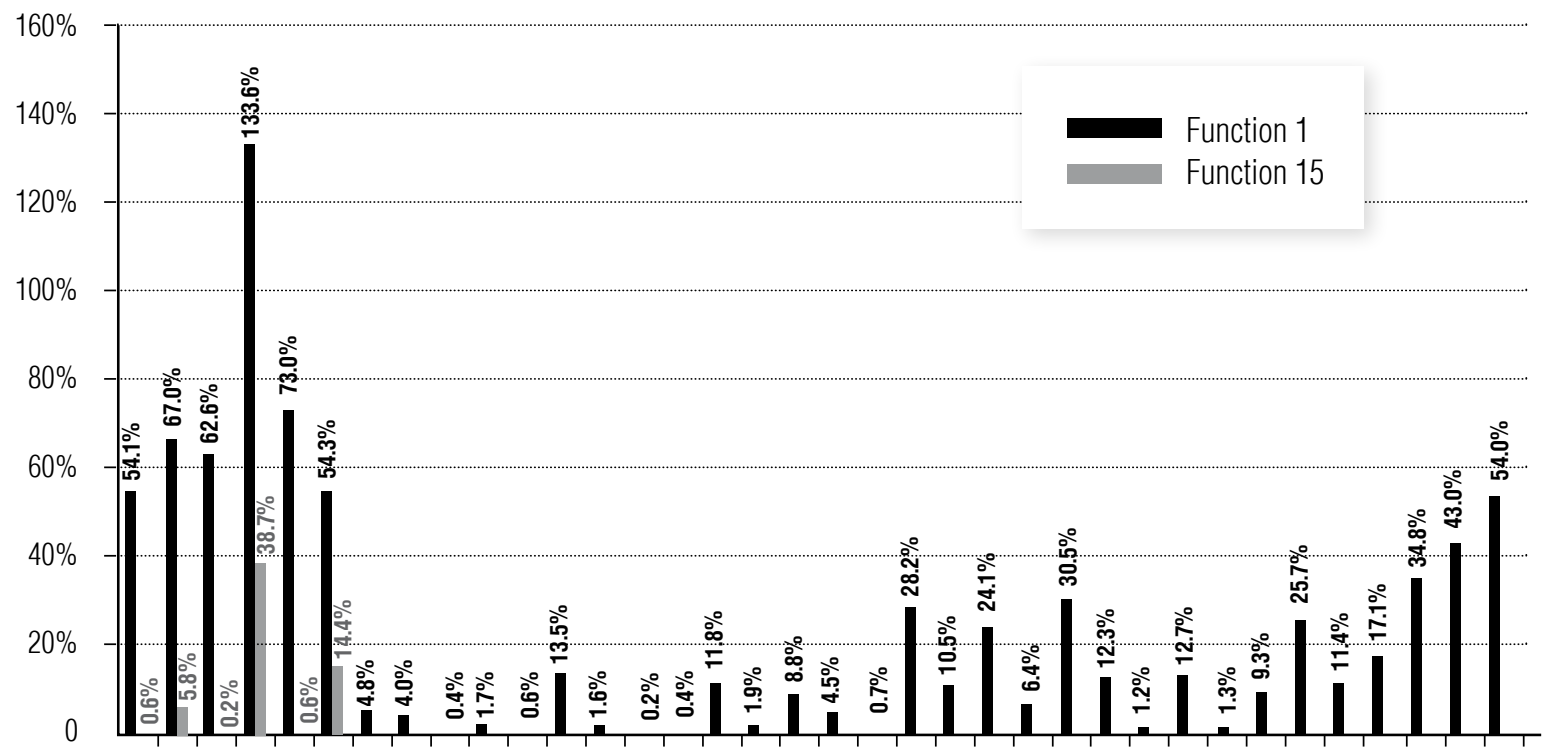

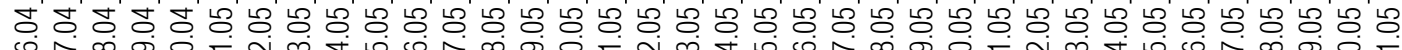

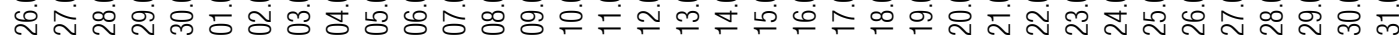

Fig. 9. APE forecast errors of the daily number of Moscow citizens infected with the Wuhan coronavirus 26 April - 31 May 2020 according to functions 1 and 15 (Table 3, Figure 8, [19]) 


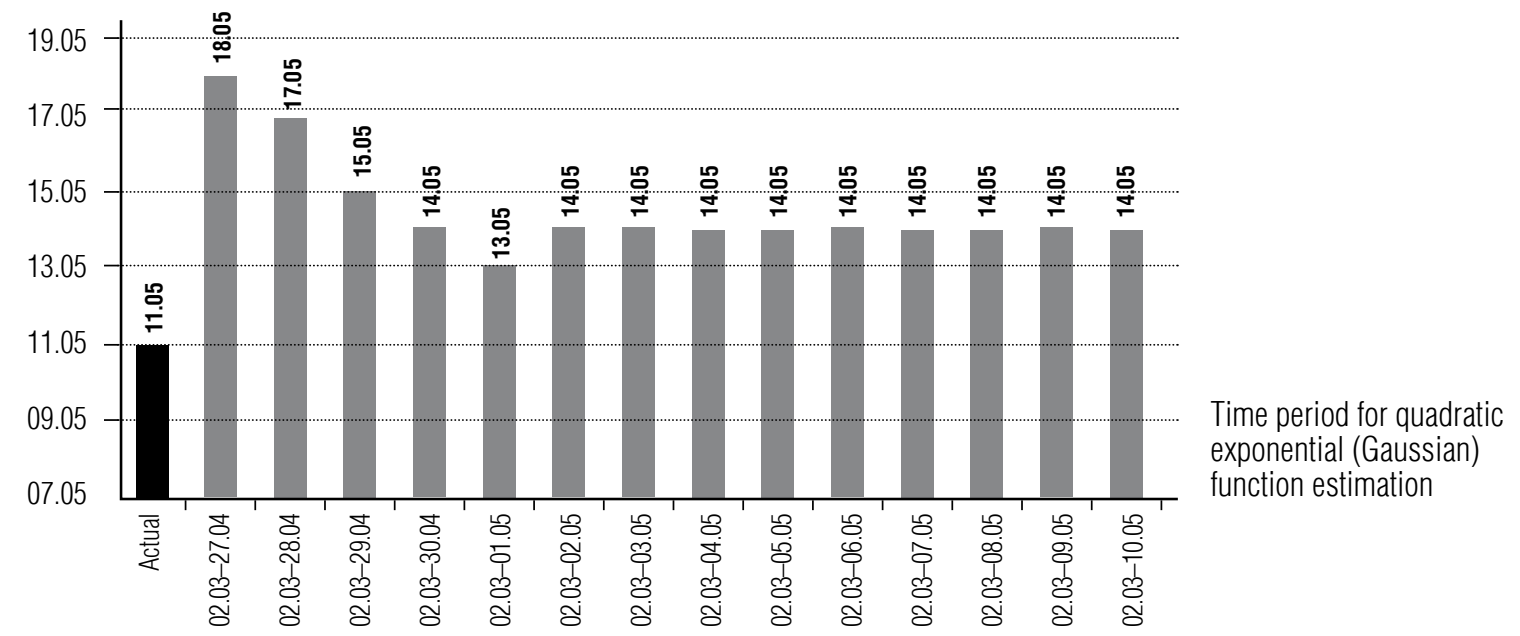

Fig. 10. Actual and predicted dates of the peak number of Wuhan coronavirus-infected Russian citizens according to function (2) estimated from 2 March to 27 April - 10 May 2020. Source: [19]

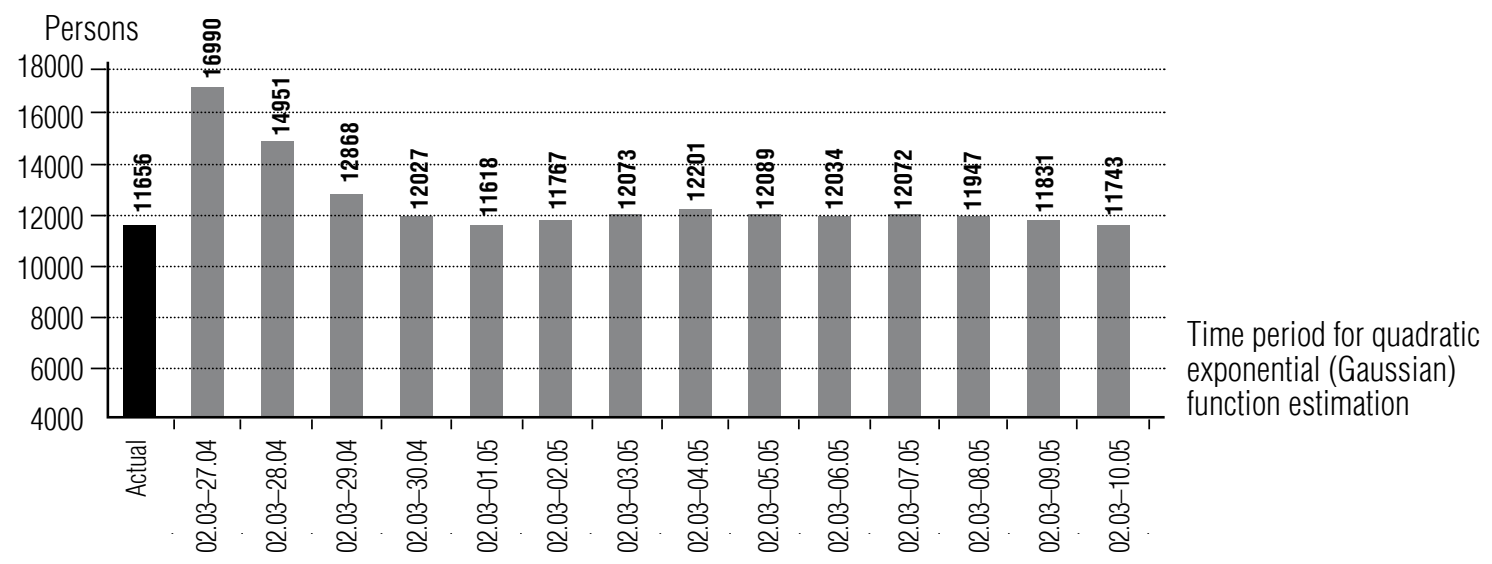

Fig. 11. Actual and predicted peak number of Russian citizens infected with the Wuhan coronavirus according to function (2) estimated from 2 March to 27 April - 10 May 2020, persons Source: [19]

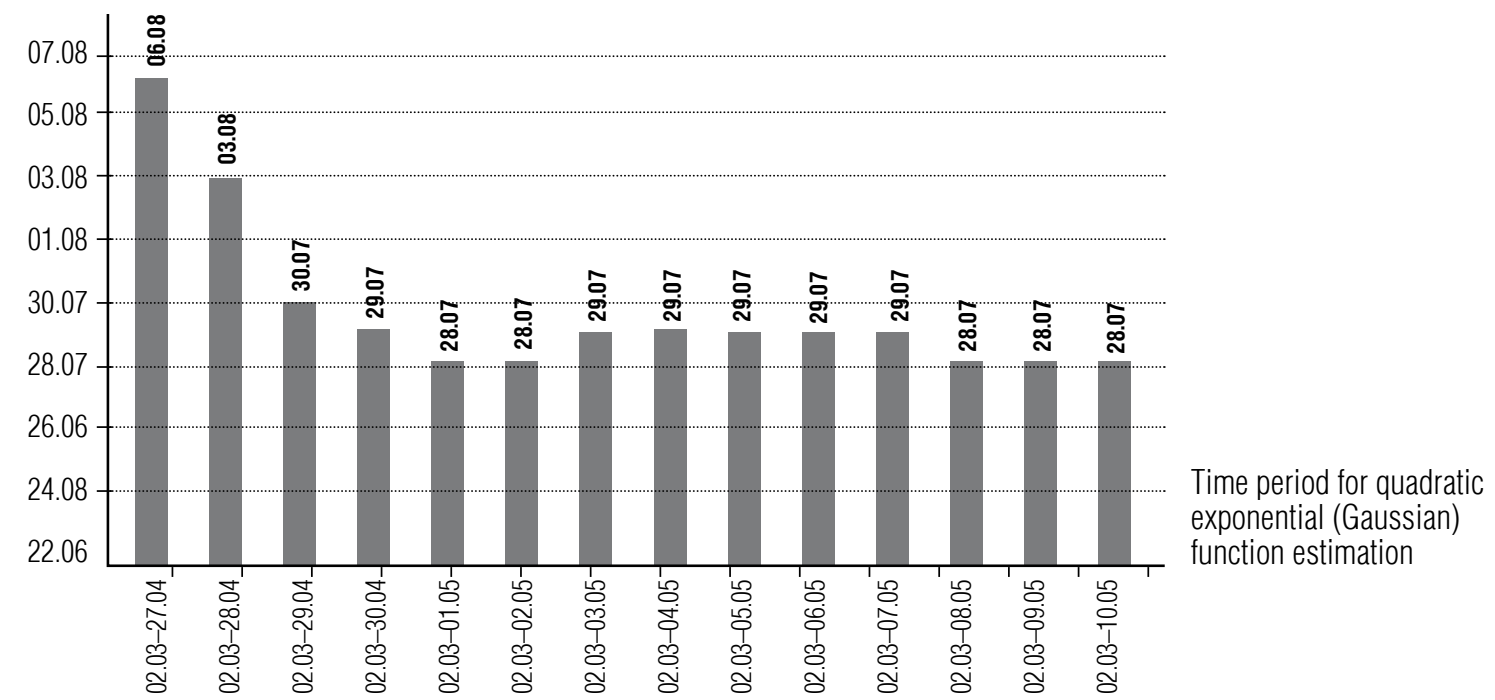

Fig. 12. The predicted dates for the onset of zero (unit) values of the number of Russian citizens infected with the Wuhan coronavirus according to function (2) estimated from 2 March to 27 April - 10 May 2020. Source: [19] 


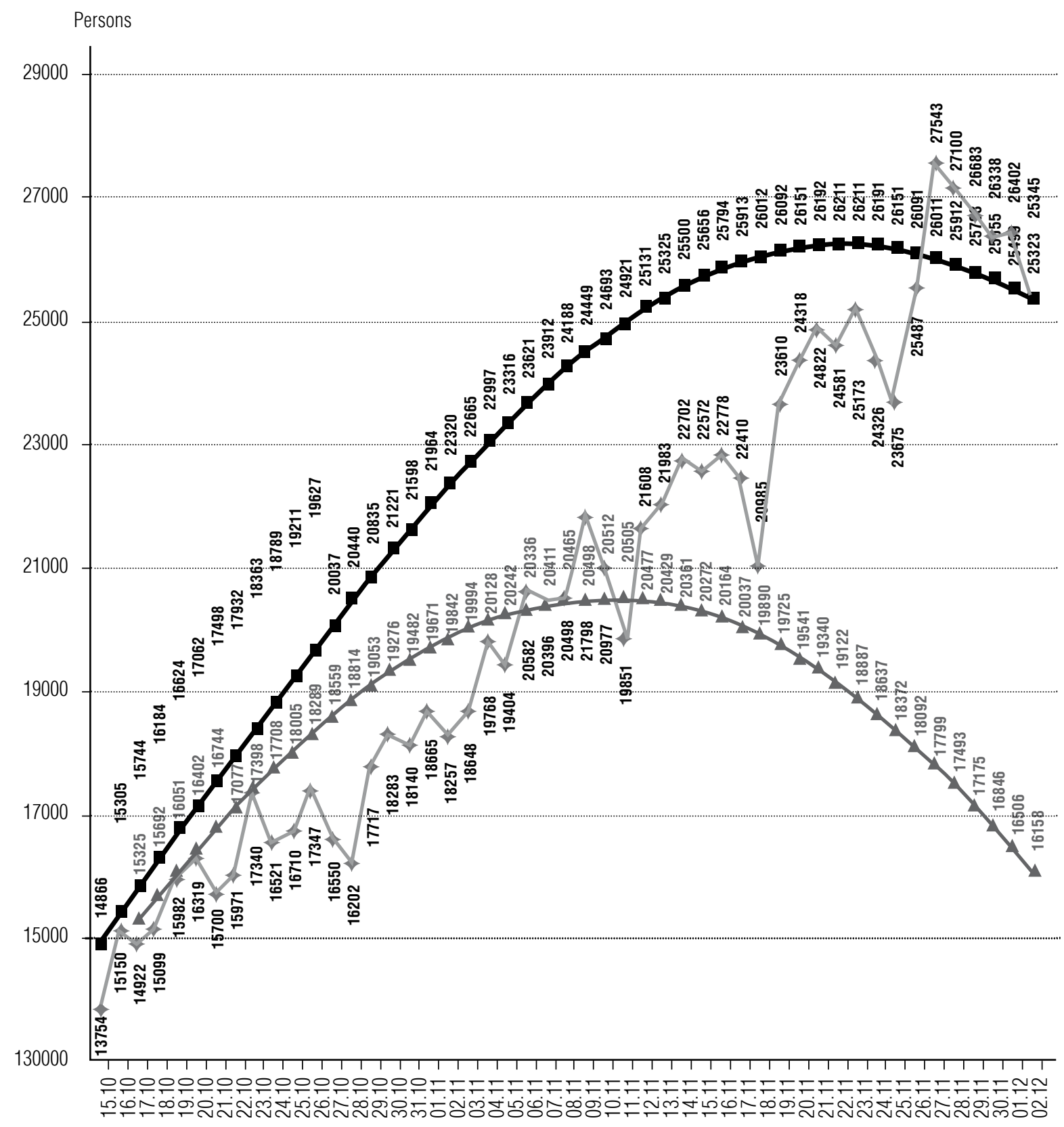

$\longrightarrow$ Actual $\longrightarrow$ Function 3a (Table 4) $\longrightarrow$ Function 4a (Table 4)

Fig. 13. Actual and forecasted values of the officially published daily number of people infected with the Wuhan coronavirus in Russia

for 15 October - 2 December 2020 according to functions 3a and 4a (Table 4)

infected with the Wuhan coronavirus, which appeared in the first days of June 2020, were caused by certain factors in mid-May - early June 2020: the weakening and subsequent cancellation of the strict isolation regime (length of which occupied the main part of the length of the time intervals for the function (2) econometric estimation), the availability of free testing for the Wuhan coronavirus and for the antibodies (which brought an element of greater 
randomness to the indicator of the daily number of Wuhan coronavirus infection).

Despite these considerations, it seems to us possible to use the above methodology for forecasting the fall-winter phase of the spread of the officially published (registered) cases of the Wuhan coronavirus in Russia. Indeed after some stabilization in August further statistics indicate an increase in cases of infection. First, we proceed with finding the pivot point (date) of growth which, as illustrated by the statistics, is 22 September 2020 .

It should be noted that functions (2) in the time intervals from 22 September to 13-31 October 2020 describe quite adequately from the point of view of classical econometric criteria the fall dynamics of the officially published daily number of people infected with the Wuhan coronavirus in Russia. One of them is function 4a, estimated from 22 September to 16 October: it is most accurately predicted from 17 October to 20 November 2020 (for 35 days ahead) with an average $A P E$ error of $6.5 \%$ (Table 4, Figures 13 and 14). However, starting from 19 November the forecast errors of the 4a function begin to grow, and the actual values from 19 November to 2 December 2020 are between the predicted values of the $3 \mathrm{a}$ and $4 \mathrm{a}$ functions, approaching the predicted values of the $3 \mathrm{a}$ function, the peak of which is expected on 22-23 November 2020 with 26211 persons (Figures 13 and 14). The average $A P E$ forecast error for 19 November 2 December 2020 (14 days ahead) for function $3 \mathrm{a}$ is $5.3 \%$. Thus, functions $3 \mathrm{a}$ and $4 \mathrm{a}$ indicate a forecast corridor with the $A P E$ arithmetic mean error for 7 weeks, which does not exceed $7 \%$.

Thus, function (2) can be used for further forecasting. According to this function forecasts (Table 4), the autumn-spring phase of the Wuhan coronavirus spread in Russia may reach its peak on 31 October - 10 November 2020 (17.1-20.5 thousand people per day) and subside by 4 March - 15 April 2021, when the total number of infected people reaches 2.2-2.6 million (functions 4a-6a from Table 4, Figure 15).
Under the worst-case scenarios, the officially published peak could be reached 26-30 thousand people per day on 23-30 November 2020 and the epidemic will subside by $5-30$ May 2021 when a total number of infected will be equal to 3.4-3.9 million people (functions 2a-3a from Table 4, Figure 15).

In the worst case scenario, the projected officially published peak population can reach 38 thousand people per day on 11 December 2020 , and the spread of the second phase of the virus will stop on 29 June 2021 with the total number of infected 5 million people (function 1o from Table 4, Figure 15).

It appears to us that the predicted values of the daily number of Russian citizens infected with the Wuhan coronavirus can serve as an input parameter for a modified production function.

The spread of the Wuhan coronavirus in Russia reduced, first of all, the level of use of almost all production factors: fixed assets - due to the temporary closure of many enterprises and organizations from 25 March to 11 May 2020; labor - due to the forced isolation of some citizens due to the coronavirus disease or close contacts with virus carriers; the transport part of the infrastructure - due to a decrease in the number of passenger flights, rail and sea transport. The only factor of production, the use of which has sharply increased during the period of restrictive measures on coronavirus and the transition of most people to remote communication and work, is the communication part of the infrastructure.

Thus, the modified Russian macroeconomic production function in regard to Wuhan coronavirus restrictions for 2020 looks as follows:

$$
Y_{t}=\mathrm{e}^{\alpha}\left(z_{t} K_{t}\right)^{\beta}\left(v_{t} L_{t}\right)^{1-\beta}\left(w_{T t} I_{T t}+w_{C t} I_{C t}\right)^{\gamma},
$$

where $v_{t}$ is the average annual rate of labor capacity use for year $t$;

$I_{T t}$ is the transport component of infrastructure for year $t$; 


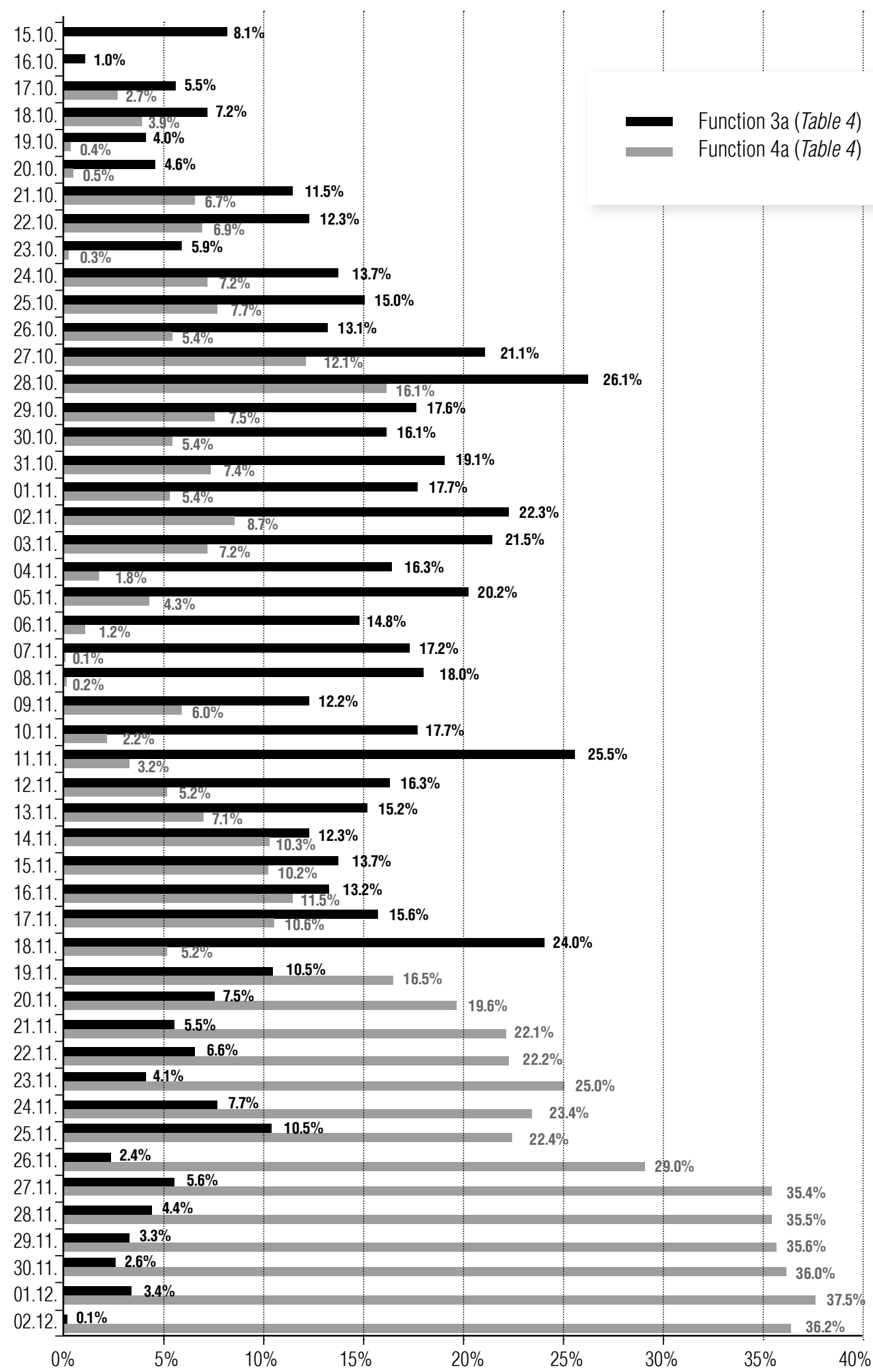

Fig. 14. APE forecast errors of the officially published daily number of people infected with the Wuhan coronavirus in Russia for 15 October - 2 December 2020 according to functions 3a and 4a (Figure 13), persons 


\section{Results of econometric study for the quadratic exponential (Gaussian) function (2) of the officially published daily number of Wuhan coronavirus-infected Russian citizens, fall 2020}

\begin{tabular}{|c|c|c|c|c|c|c|c|c|c|c|}
\hline \multirow[b]{2}{*}{ № } & \multirow[b]{2}{*}{$\begin{array}{l}\text { Time } \\
\text { period }\end{array}$} & \multicolumn{3}{|c|}{$\begin{array}{l}\text { Coefficients } \\
t \text {-statistics }\end{array}$} & \multirow[b]{2}{*}{$R^{2}$} & \multirow[b]{2}{*}{$D W$} & \multicolumn{2}{|c|}{$\begin{array}{l}\text { Daily infection } \\
\text { peak forecast } \\
\text { for } 2020\end{array}$} & \multicolumn{2}{|c|}{$\begin{array}{l}\text { Onset of zero (unit) daily infection } \\
\text { forecast for } 2021\end{array}$} \\
\hline & & $a$ & $b$ & $c$ & & & date & $\begin{array}{l}\text { number } \\
\text { of } \\
\text { infected, } \\
\text { persons }\end{array}$ & date & $\begin{array}{l}\text { total number of people } \\
\text { infected since the } \\
\text { beginning of the epidemic, } \\
\text { million persons }\end{array}$ \\
\hline $1 a$ & $22.09-12.10$ & $\begin{array}{c}-0.0003 \\
(-1.75)\end{array}$ & $\begin{array}{l}0.1613 \\
(2.32)\end{array}$ & $\begin{array}{l}12.46 \\
(1.66)\end{array}$ & 0.99 & 1.39 & 11.12 & 38362 & 29.06 & 5.0 \\
\hline $2 a$ & $22.09-13.10$ & $\begin{array}{c}-0.0003 \\
(-2.37)\end{array}$ & $\begin{array}{l}0.1848 \\
(3)\end{array}$ & $\begin{array}{l}14.96 \\
(2.26)\end{array}$ & 0.99 & 1.36 & 30.11 & 30191 & 30.05 & 3.9 \\
\hline $3 a$ & $22.09-14.10$ & $\begin{array}{c}-0.0004 \\
(-3)\end{array}$ & $\begin{array}{l}0.2040 \\
(4)\end{array}$ & $\begin{array}{l}17.01 \\
(2.90)\end{array}$ & 0.99 & 1.33 & $\begin{array}{l}22.11 \\
23.11\end{array}$ & 26211 & 5.05 & 3.4 \\
\hline $4 a$ & $22.09-16.10$ & $\begin{array}{c}-0.0005 \\
(-4)\end{array}$ & $\begin{array}{l}0.2540 \\
(5)\end{array}$ & $\begin{array}{c}22.35 \\
(4)\end{array}$ & 0.99 & 1.51 & 10.11 & 20512 & 5.04 & 2.6 \\
\hline $5 a$ & $22.09-19.10$ & $\begin{array}{c}-0.0006 \\
(-7)\end{array}$ & $\begin{array}{c}0.2803 \\
(8)\end{array}$ & $\begin{array}{c}25.17 \\
(6)\end{array}$ & 0.99 & 1.57 & 6.11 & 18892 & 23.03 & 2.4 \\
\hline $6 a$ & 22.09-28.10 & $\begin{array}{c}-0.0007 \\
(-15)\end{array}$ & $\begin{array}{c}0.3350 \\
(16)\end{array}$ & $\begin{array}{l}31.12 \\
(14)\end{array}$ & 0.99 & 1.56 & 31.10 & 17150 & 4.03 & 2.2 \\
\hline
\end{tabular}

Source of statistical data for econometric research: Communication Center of the Russian Federation Government (стопкоронавирус.рф)

$I_{C t}$ is the communication component of infrastructure for year $t$;

$w_{T t}$ is average annual rate of infrastructure transport component capacity use for year $t$

$w_{C t}$ is average annual rate of infrastructure communication component capacity use for year $t$.

It is reasonable to assume that the average monthly rate of labor capacity use for the month $\tau$ will represent some function $F$ which is a function of strict isolation depending on the number of people with Wuhan coronavirus disease and persons in contact with them. All those persons are out of the labor force completely or partially due to temporal illness or quarantine. The function increases by the total

Table 4.

\section{)}




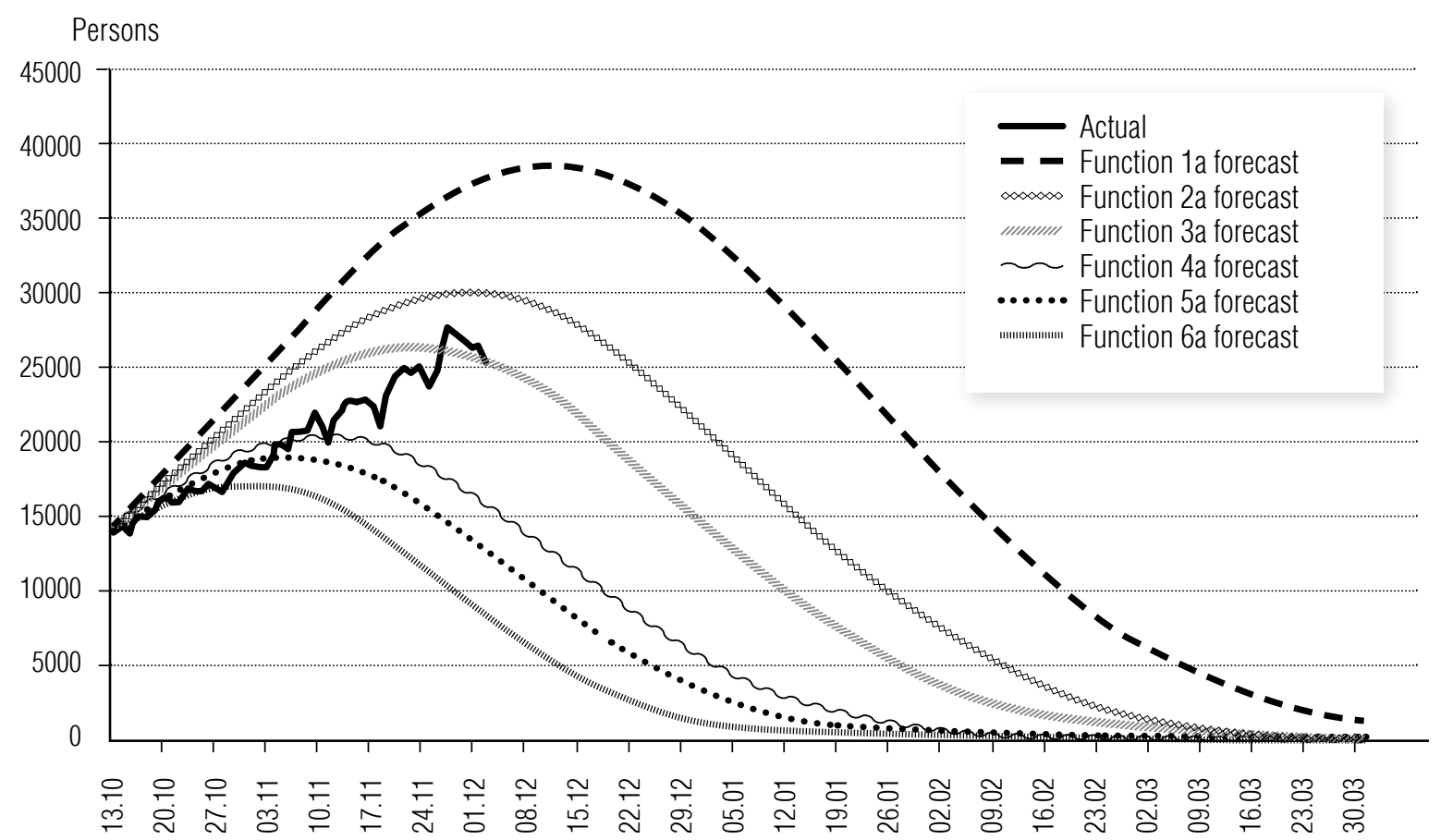

Fig. 15. Actual values (from 13 October to 2 December 2020) and forecasted values (for 13 October 2020 - 31 March 2021) of the officially published daily number of Russian citizens infected with the Wuhan coronavirus (Table 4)

depending on the fall of this indicator below thresholds:

$$
z_{\tau}=z\left(y_{\tau, T}\right)=\left\{\begin{array}{l}
z_{0}, y_{\tau, T}<\tilde{y}_{0} \\
z_{1}, \tilde{y}_{0} \leq y_{\tau, T} \leq \tilde{y}_{1} \\
z_{2}, \tilde{y}_{1} \leq y_{\tau, T} \leq \tilde{y}_{2} \\
z_{3}, y_{\tau, T}>\tilde{y}_{2}
\end{array}\right.
$$

where $\tilde{y}_{i}$ are the epidemic thresholds of the daily number of people infected with the Wuhan coronavirus in accordance with the three stages of coronavirus restrictions in Russia introduced by Rospotrebnadzor (Russian Federal Service for Surveillance on Consumer Rights), $i=1,2,3$. Moreover, $z_{0}$ corresponds to the pre-coronavirus level of production capacity use. It is obvious that $z_{0}>z_{1}>z_{2}>z_{3}$, i.e. the function decreases with respect to the number of people infected with the Wuhan coronavirus and the values of epidemic thresholds.

The function of the average monthly rate capacity use of the transport component of the infrastructure $w_{T t}$ will have the same piecewise linear form; it will also decrease with respect to the number of infected people.

On the contrary, the function of the average monthly rate capacity use of the communication component of the infrastructure $w_{C t}$ will increase according to the number of people infected with the Wuhan coronavirus and epidemic thresholds:

$$
w_{C \tau}=w_{C \tau}\left(y_{\tau, T}\right)=\left\{\begin{array}{l}
w_{C 3}, y_{\tau, T}>\tilde{y}_{2} \\
w_{C 2}, \tilde{y}_{1} \leq y_{\tau, T} \leq \tilde{y}_{2} \\
w_{C 1}, \tilde{y}_{0} \leq y_{\tau, T} \leq \tilde{y}_{1} \\
w_{C 0}, y_{\tau, T}<\tilde{y}_{0}
\end{array}\right.
$$

i.e. $w_{C 0}<w_{C 1}<w_{C 2}<w_{C 3}$, where $\tilde{y}_{i}$ are the epidemic thresholds of the daily number of people infected with the Wuhan coronavirus in accordance with the 3 stages of coronavirus restrictions in Russia introduced by Rospotrebnadzor, $i=1,2,3$.

Average annual values of factors capacity use rates are calculated as arithmetic mean of their monthly values: 


$$
\begin{gathered}
z_{t}=\frac{1}{12} \sum_{\tau=1}^{12} z_{\tau}, v_{t}=\frac{1}{12} \sum_{\tau=1}^{12} v_{\tau}, \\
w_{T t}=\frac{1}{12} \sum_{\tau=1}^{12} w_{T \tau}, w_{C t}=\frac{1}{12} \sum_{\tau=1}^{12} w_{C \tau} .
\end{gathered}
$$

We should note that the role of the infrastructure communication component $w_{C t} I_{C t}$ increases with the Wuhan coronavirus epidemic and the associated restrictive measures, which replaces, to a certain extent, the transport component $w_{T t} I_{T t}$.

\section{Conclusion}

We offer the econometric study of macroeconomic production function of the Russian Federation with transport and communication infrastructure (the fixed assets average annual value of the Russian transport and communications sectors) for 1990-2018. Our research demonstrates that in 2010-2018 the GDP elasticity to production infrastructure is decreasing. We explain it by the reduction in the volume of capital investments in infrastructure sectors' fixed assets.

In addition, we offer an analytical modification of the macroeconomic production function for 2020 in the context of the spread of the Wuhan coronavirus among the Russian population. In was done by introducing into this function the average annual rates of labor and infrastructure capacity use, which, along with the average annual rate of fixed assets capacity use are functions of the predicted values of the daily number of the infected Russian citizens. We make econometric forecasts of the officially published daily number of infected Russian population for fall 2020 - spring 2021. These forecasts have been made on the basis of timedependent quadratic exponential (Gaussian) function estimated by least squares method.

We would like to emphasize that the modification of the Russian macroeconomic production function in regard to the spread of the Wuhan coronavirus in 2020 was carried out in an analytical form. Its practical implementation, hindered at the moment by the lack of annual and, partly, of monthly statistical data for the current year, will be carried out at the next stage of our research.

\section{Acknowledgments}

This research is supported by the Russian Foundation for Basic Research (project No. 20-010-00629 A).

The authors express their sincere gratitude for the valuable advice and useful remarks to Prof. Yuri N. Blagoveshchensky and Prof. Eduard F. Baranov.

\section{References}

1. The President of Russia (2019) Message from the President of Russia to the Federal Assembly. Moscow, Kremlin, 20 February 2019. Available at: http://kremlin.ru/events/president/news/59863 (accessed 01 October 2020) (in Russian).

2. Afanasiev A.A., Ponomareva O.S. (2020) Some problems of the development and modernization of the Russian economy infrastructure. Proceedings of the 21st Russian Symposium on Strategic Planning and Enterprise Development. Section 5 "Forecasting Problems of the Enterprises' Activities". Moscow, 10-11 November 2020, pp. 652-654 (in Russian).

3. Dubelir G.D. (1910) City planning. Saint Petersburg: Slovo (in Russian).

4. Dubelir G.D. (1912) City streets and pavements. Kiev: A.M. Ponomarev (in Russian).

5. Dubelir G.D. (1912) Dirt roads, their construction and maintenance. Saint Petersburg: Slovo (in Russian).

6. Dubelir G.D., Zakharov G.F., Til B.I. (1934) Operation of carriage roads. Leningrad: OGIS-Gostransizdat (in Russian).

7. Dubelir G.D., Korneev B.G., Kudryavtsev M.N. (1939) Fundamentals of road design. Leningrad, Moscow: Publishing house of the People's Commissariat of the RSFSR (in Russian). 
8. Zavelsky M.G. (2009) Industrial infrastructure and economic development. Problems of Regional Economics, vol. 1, pp. 77-81 (in Russian).

9. Laverov N.P., Alekseevsky N.I., Berdnikov S.V., Gliko A.O., Granberg A.G., Danilov-Danilyan V.I., Dynkin A.A., Zemskoy Yu.A., Zolotarev P.S., Ivanter V.V., Kasimov N.S., Leonov Yu.G., Makosko A.A., Matishov G.G., Makhutov N.A., Osipov V.I., Pappe Ya.Sh., Filin B.N., Chalov R.S. (2008) Expertise on the project of construction of Eurasia international sea channel. Problems of national security: expert opinions, analytical materials, proposals. Moscow, Nauka (in Russian).

10. Livshits V.N., Mironova I.A., Shvetsov A.N. (2014) Transport infrastructure: effectiveness of strategic decisions. International Journal of Management Theory and Practice, no 7, pp. 78-89 (in Russian).

11. Posamantir E.I. (2014) Transport infrastructure development strategy: macroeconomic assessment of options. Audit and Financial Analysis, no 1, pp. 128-136 (in Russian).

12. Sadovnichii V.A., Osipov G.V., Akaev A.A., Malkov A.S., Shulgin S.G. (2018) Socio-economic effectiveness of the railway network development in Siberia and the Far East: Mathematical simulation and forecast. Economy of Region, vol. 14, no 3, pp. 758-777 (in Russian).

13. Makarov V.L. (2003) Economy of knowledge. Lessons for Russia. Herald of the Russian Academy of Sciences, vol. 73, no 5, pp. 450-456 (in Russian).

14. Afanasiev A.A., Ponomareva O.S. (2014) The aggregate production function of Russian economy in 1990-2012. Economics and Mathematical Methods, vol. 50, no 4, pp. 21-33 (in Russian).

15. Afanasiev A.A., Ponomareva O.S. (2020) The macroeconomic production function of Russia in 1990-2017. Economics and Mathematical Methods, vol. 56, no 1, pp. 67-78 (in Russian).

16. Rosstat (2019) Russia in figures 2019: Statistical handbook. Moscow: Rosstat (in Russian).

17. Rosstat (2019) Russian statistical yearbook 2019: Statistical handbook. Moscow: Rosstat (in Russian).

18. IMEMO RAS (2020) Russian Economic Barometer. Quarterly Bulletin, no 2 (in Russian).

19. Afanasiev A.A. Execution of the econometric forecast for the daily number of Moscow citizens infected with the Wuhan coronavirus (26 April - 9 May 2020). Available at:

https://istina.msu.ru/conferences/presentations/297636272/ (accessed 15 August 2020) (in Russian).

20. Afanasiev A.A. Econometric forecasting of the daily number of Moscow citizens infected with the Wuhan coronavirus from March to July 2020 (full version of 25 April 2020). Available at: https://istina.msu.ru/conferences/presentations/294603297/ (accessed 15 August 2020) (in Russian).

21. Afanasiev A.A. Econometric forecasting of the daily number of Moscow citizens infected with the Wuhan coronavirus from March to July 2020 (abridged version of 25 April 2020). Available at: https://indem.ru/coronavirus/Forecast_CV-19_In_Moscow.pdf (accessed 15 August 2020) (in Russian).

22. Shereen M.A., Khan S., Kazmi A., Bashir N., Siddique R. (2020) COVID-19 infection: Origin, transmission, and characteristics of human coronaviruses. Journal of Advanced Research, no 24, pp. 91-98. DOI: $10.1016 /$ j.jare.2020.03.005.

23. Chinese Academy of Sciences (2020) Wuhan coronavirus has strong ability to infect humans. Press release, 21 January 2020. Available at: https://view.inews.qq.com/w2/20200121A0M08X00?tbkt=F\&strategy=\& openid=o04IBALMrLyGDxbWNOPoDM1IfG-s\&uid=\&refer=wx_hot (accessed 15 August 2020).

\section{About the authors}

\section{Anton A. Afanasiev}

Dr. Sci. (Econ.);

Leading Researcher, Laboratory of Social Simulation, Central Economics and Mathematics Institute, Russian Academy of Sciences, 47, Nakhimovsky Prospect, Moscow 117418, Russia;

E-mail: aanton@cemi.rssi.ru

ORCID: 0000-0002-0300-5064

\section{Olga S. Ponomareva}

Senior Researcher, Laboratory of Institutional Dynamics, Central Economics and Mathematics Institute, Russian Academy of Sciences, 47, Nakhimovsky Prospect, Moscow 117418, Russia;

E-mail: fondf@cemi.rssi.ru 